forthcoming in Economics Letters

\title{
Efficiency Wages, Nominal Rigidities, and the Cyclical Behavior of Real Wages and Marginal Cost
}

\author{
Michael T. Kiley ${ }^{1}$ \\ Division of Research and Statistics \\ Federal Reserve Board
}

April 24, 1997

\begin{abstract}
I present a model in which efficiency wages generate acyclical real wages, but do not lower the sensitivity of marginal cost to output or increase price stickiness.

Consideration of previous models suggests that efficiency wages are a poor real rigidity.
\end{abstract}

keywords: efficiency wages, nominal price rigidity

JEL Codes: E24, E31, E32

${ }^{1}$ Address: Division of Research and Statistics, Federal Reserve Board, Washington, DC 20551, phone: (202)452-2448, fax: (202)736-1937, e-mail: mkiley@frb.gov. The views expressed herein are solely the author's, and do not reflect those of the Federal Reserve Board or its staff. 


\section{Introduction}

Efficiency wage models may lower the response of real wages to real demand, and therefore potentially explain

1. the acyclical behavior of the real wage and the large employment fluctuations over the business cycle ${ }^{2}$

2. endogenous price stickiness from the interaction of real and nominal rigidities. ${ }^{3}$ Section 2 presents a model in which efficiency wages are paid to elicit effort, capturing the spirit of Solow (1979). In this model, acyclical real wages and large employment fluctuations easily arise, but endogenous price stickiness does not arise. The intuition is simple: effort is low when employment is high (as in many efficiency wage models, including Phelps's extension (1994) of Shapiro and Stiglitz (1984)), so marginal cost is high when output is high, even if the real wage does not increase. Relatively acyclical marginal cost is required for endogenous price stickiness, since prices are based on the marginal cost of production, not wages. Since my model does not generate acyclical marginal cost, endogenous price stickiness does not arise.

Section 3 discusses the generality of my results, which is especially important given the very simple model of section 2. My analysis of the previous literature reveals that indeed previous authors who succeed in generating acyclical real wages in an efficiency wage model do so through countercyclical effort, and hence marginal cost is significantly more cyclical than the real wage in efficiency wage models generally. This result suggests that efficiency

\footnotetext{
${ }^{2}$ Solow (1979) is an early contribution, and Yellen (1984) and Weiss (1990) provide references.

${ }^{3}$ Ball and Romer (1990); see also Ball, Mankiw, and Romer (1988) and Blanchard and Fischer (1989).
} 
wage models, as implemented in the current literature, are incapable of generating endogenous price stickiness (or, efficiency wages are not a good real rigidity to combine with nominal rigidity).

\section{A Simple Model Exploring Endogenous Price Stickiness}

\section{Endogenous Price Stickiness Defined}

The model is a two period staggered price setting model, inspired by Taylor (1980) and following Blanchard and Fischer (1989), Kiley (1996), and Chari, Kehoe and McGrattan (1996). Lower case letters throughout denote the log deviation of the variable from its steady state. Firms have market power and set prices $(\mathrm{x})$ for two periods at the start of period $\mathrm{t}$; desired prices are a constant markup over nominal marginal cost, and the chosen price is the average of the desired price over the two periods for which the price is set. Denoting real marginal cost by $\mathrm{c}$ and the price level by $\mathrm{p}$, the equation for $\mathrm{x}$ is given by

$$
x_{t}=1 / 2 E_{t-1}\left[p_{t}+c_{t}+p_{t+1}+c_{t+1}\right]
$$

where the expectations are conditioned on all information up through time $\mathrm{t}-1$. The equation for the price level (p) is given by the average of outstanding prices,

$$
p_{t}=1 / 2\left(x_{t}+x_{t-1}\right)
$$

and aggregate demand $(\mathrm{m})$ is given by the quantity equation,

$$
\mathrm{m}_{\mathrm{t}}=\mathrm{y}_{\mathrm{t}}+\mathrm{p}_{\mathrm{t}}
$$

The models considered below will imply that real marginal cost is related to output,

$$
c_{t}=b y_{t}
$$

$\mathrm{b}$ is the elasticity of marginal cost with respect to output. Finally, I assume that nominal aggregate demand is a random walk, which implies (in conjunction with (1)-(4)) that output 
and the price level are given by

$$
\begin{aligned}
& \mathrm{p}_{\mathrm{t}}=\mathrm{kp}_{\mathrm{t}-1}+1 / 2(1-\mathrm{k})\left(\mathrm{m}_{\mathrm{t}-1}+\mathrm{m}_{\mathrm{t}-2}\right), \\
& \mathrm{y}_{\mathrm{t}}=\mathrm{ky}_{\mathrm{t}-1}+\mathrm{m}_{\mathrm{t}}-1 / 2(1+\mathrm{k}) \mathrm{m}_{\mathrm{t}-1}-1 / 2(1-\mathrm{k}) \mathrm{m}_{\mathrm{t}-2},
\end{aligned}
$$

where $\mathrm{k}=\left(1-\mathrm{b}^{1 / 2}\right) /\left(1+\mathrm{b}^{1 / 2}\right){ }^{4}$

The parameter $\mathrm{k}$ indexes endogenous price stickiness; for $\mathrm{k}$ near 1, prices adjust very slowly and the output effects of nominal aggregate demand shocks are long lived, whereas for $\mathrm{k}$ near zero, prices basically adjust completely to their long run level after the two exogenously imposed periods of price stickiness have expired. In order for endogenous price stickiness to arise, marginal cost must be relatively acyclical (as b near zero implies k near 1). This point is of course well known (Blanchard and Fischer (1989) devote chapters 8 and 9 to this issue, for example). The next two sections ask if efficiency wages are a promising avenue to yield a low elasticity of marginal cost with respect to output (b), as suggested by the conventional new-Keynesian wisdom in Blanchard and Fischer (1989), Ball and Romer (1990), and Mankiw and Romer (1991).

\section{A Competitive Labor Market}

Firms set prices as above, and supply all demand at their quoted price (i.e., take output $\mathrm{Y}$ as given). The production function for output is $\mathrm{Y}=\mathrm{N}^{\mathrm{a}}$, where $\mathrm{N}$ is employment and $\mathrm{a} \leq$

1. Cost minimization implies the following first order conditions;

$$
\begin{aligned}
& \mathrm{W}=\mathrm{CaY} / \mathrm{N}, \\
& \mathrm{Y}=\mathrm{N}^{\mathrm{a}},
\end{aligned}
$$

where $\mathrm{W}$ is the real wage and marginal cost $\mathrm{C}$ is the lagrange multiplier on the output

\footnotetext{
${ }^{4}$ Blanchard and Fischer (1989), chapter 8, and Chari, Kehoe, and McGrattan (1996).
} 
constraint. Log-linearizing and eliminating constants yields

$$
\begin{aligned}
& \mathrm{w}=\mathrm{c}+\mathrm{y}-\mathrm{n}, \\
& \mathrm{y}=\mathrm{an} .
\end{aligned}
$$

Consumers solve a static utility maximization problem to determine labor supply;

consumption equals labor income (WN) and the utility function is given by $\mathrm{WN}-\mathrm{N}^{1+s} /(1+\mathrm{s})$, which implies that the labor supply elasticity is given by $1 / \mathrm{s}$. Utility maximization then implies that

$$
\mathrm{W}=\mathrm{N}^{\mathrm{s}} \text {, }
$$

or in logs

$$
\mathrm{w}=\mathrm{sn} .
$$

Solving (7)-(9) for employment, wages, and marginal cost as functions of output yields

$$
\begin{aligned}
& \mathrm{n}=\mathrm{y} / \mathrm{a}, \\
& \mathrm{w}=\mathrm{sy} / \mathrm{a} . \\
& \mathrm{c}=[1+\mathrm{s}-\mathrm{a}] \mathrm{y} / \mathrm{a} .
\end{aligned}
$$

Equation (12) reveals the unsurprising conclusion that the cyclicality of marginal cost (b in (4)) is determined by returns to labor in production and the elasticity of labor supply. Since most estimates of the labor supply elasticity are fairly low (large s), (12) indicates that competitive labor market models have a tough time generating endogenous price stickiness (low b and high k in (5) and (6)) as in Blanchard and Kiyotaki (1987), Blanchard and Fischer (1989), Ball and Romer (1990), and Chari, Kehoe, and McGrattan (1996).

\section{An Efficiency Wage Labor Market}

Assume that firms have enough power in the labor market to set wages and choose 
employment at a level which keeps consumers utility at its reservation level (i.e., the level of utility when labor income and employment are zero). However, the wage and employment choices of the firm affect the effort level of the employee because effort causes disutility, and wages are divorced from effort. I will not explore why wages are not related to effort, and simply note that possible reasons include fairness and transparency concerns in the workplace, as in Weiss (1980), and that in fact wages do appear to be divorced from productivity differences in workers (Weiss $(1980,1990))$. Assuming that utility is linear in consumption, and the disutility of work is related to the intensity of work hours (EN, where E is effort) yields a utility function, $\mathrm{U}=\mathrm{WN}-(\mathrm{EN})^{1+s} /(1+\mathrm{s})$. Combining this utility function with a reservation utility of zero and the above assumptions regarding firms' wage setting power yields the effort function of consumers,

$$
\mathrm{E}=\mathrm{dW}^{1 /(1+s)} \mathrm{N}^{-s /(1+s)} \text {, where } \mathrm{d} \text { is an unimportant constant, }
$$

which reveals that in this model effort is increasing in the wage and decreasing in employment. The model is therefore quite similar to Solow (1979) in which effort is observable (as here) but wages are divorced from effort, and shares the basic flavor of monitoring models of efficiency wages (such as Shapiro and Stiglitz (1984)) in which effort is imperfectly observable. Section 3 will discuss the connection in more detail.

Modifying the production function of the previous section so that output is a function of effective labor input (EN) rather than $\mathrm{N}$ and inserting (13) into this production function yields

$$
\mathrm{Y}=\mathrm{f}(\mathrm{NW})^{\mathrm{a} /(1+\mathrm{s})} \text {, where } \mathrm{f} \text { is an unimportant constant, }
$$

so output depends on both employment and the wage, as in Solow (1979) and Akerlof and 
Yellen (1985). Minimizing cost (WN) with respect to W and N subject to (14) yields the first order conditions

$$
\begin{aligned}
& \mathrm{W}=(\mathrm{CaY} / \mathrm{N}) /(1+\mathrm{s}), \\
& \mathrm{N}=(\mathrm{CaY} / \mathrm{W}) /(1+\mathrm{s}) .
\end{aligned}
$$

Log-linearizing these first order conditions and (14) (and eliminating constants) yields

$$
\begin{aligned}
& \mathrm{w}=\mathrm{c}+\mathrm{y}-\mathrm{n}, \\
& \mathrm{n}=\mathrm{c}+\mathrm{y}-\mathrm{w}, \\
& \mathrm{y}=(\mathrm{a} /(1+\mathrm{s}))[\mathrm{n}+\mathrm{w}]
\end{aligned}
$$

Inspection of (15)-(17) immediately reveals that these equations possess a unique solution for marginal cost in terms of output fluctuations, but an infinite set of solutions for the wage and employment.

In particular, if wages are completely acyclical the following solutions for the wage and employment obtain

$$
\begin{aligned}
& \mathrm{w}=0 \mathrm{y}, \\
& \mathrm{n}=(1+\mathrm{s}) \mathrm{y} / \mathrm{a} .
\end{aligned}
$$

As in Solow (1979), my efficiency wage model can generate acyclical wages and exacerbated employment fluctuations (relative to the competitive model). What is interesting is that for every w,n solution, marginal cost satisfies

$$
\mathrm{c}=[1+\mathrm{s}-\mathrm{a}] \mathrm{y} / \mathrm{a}
$$

which is exactly the same value of the elasticity of marginal cost with respect to output (b) as in the competitive model. Therefore, my efficiency wage model generates acyclical real wages, but has no effect on endogenous price stickiness. 
This result is intuitive. Prices are based on marginal cost, which depends both on the wages paid to workers and on the productivity of workers. When employment is high, effort is low, and hence marginal cost is high even when wages are acyclical.

\section{Relationship to Previous Work}

Previous research leaves the clear impression that efficiency wages will enhance the degree of endogenous price stickiness $\mathrm{k}$ from the low values implied by the competitive labor market model with inelastic labor supply; the clearest examples are Akerlof and Yellen (1985) and Ball and Romer (1990). Reconciling my results with these is simple. First, Akerlof and Yellen simply assume a reduced form for effort which is solely a function of the wage $(\mathrm{E}(\mathrm{W}))$, and therefore the employment effects on effort which underly my results are absent. Ball and Romer do the same, but attempt to justify this assumption through Shapiro and Stiglitz's effort elicitation model (1984) in which effort is discrete $(0,1)$, and in equilibrium effort is always "on" (=1). Therefore, in equilibrium and in the special case of constant returns to labor, marginal cost is simply the real wage. Ball and Romer then demonstrate that if the real wage is acyclical and equals marginal cost, endogenous price stickiness is enhanced.

My results are more relevant than those of Ball and Romer (1990) for essentially two reasons. First, Kimball (1994) demonstrates that the Shapiro and Stiglitz model with constant equilibrium effort is unable to quantitatively generate acyclical real wages. ${ }^{5}$ This critique of

\footnotetext{
${ }^{5}$ Danthine and Donaldson (1990,1995) and Gomme (1994) complement the results of Kimball (1994) by demonstrating through numerical simulation of efficiency wage models that the constant effort assumption is inconsistent with acyclical real wages.
} 
efficiency wages is separate from, but complementary to, my insight that even if real wages are acyclical marginal cost may still be strongly procyclical. Second, Gomme (1994) and Uhlig and $\mathrm{Xu}$ (1996) succeed in generating acyclical real wages in shirking/continuous effort elicitation models similar to Shapiro and Stiglitz (1984), but need countercyclical effort (and numerical solutions due to the complexity of their models). The intuition for countercyclical effort in these models with continuous effort (as in Phelps (1994)) is very similar to that above. Specifically, effort is elicited in shirking-monitoring models through high wages and the threat of unemployment; when output and employment requirements are high, the threat of unemployment will be low, and effort will be low if wages are acyclical. Therefore, marginal cost will be significantly more procyclical than real wages, and endogenous price stickiness will be low.

\section{Conclusion}

I have demonstrated that a simple efficiency wage story which generates completely acyclical real wages does not increase endogenous price stickiness, because the acyclical real wage requires countercyclical effort and hence procyclical marginal cost. While the model demonstrating this point is exceedingly simple, previous research which successfully generates acyclical real wages in shirking/effort efficiency wage models also requires countercyclical effort. Since marginal cost will increase when effort is low even if wages are acyclical, endogenous price stickiness is unlikely to be significantly enhanced by the current generation of efficiency wage/business cycle models. 


\section{References}

Akerlof, G.A. and J.L. Yellen. 1985, A Near-Rational Model of the Business Cycle, with Wage and Price Inertia, Quarterly Journal of Economics 100, 823-838.

Ball, L., N.G. Mankiw, and D. Romer. 1988, The New-Keynesian Economics and the OutputInflation Tradeoff, Brookings Papers on Economic Activity 1, 1-65.

Ball, L. and D. Romer. 1990, Real Rigidities and the Non-neutrality of Money, Review of Economic Studies 57, 183-203.

Blanchard, O.J. and N. Kiyotaki. 1987, Monopolistic Competition and the Effects of Aggregate Demand, American Economic Review 77, 647-666.

Blanchard, O.J. and S. Fischer. 1989, Lectures on Macroeconomics (MIT Press, Cambridge).

Chari, V.V., P.J. Kehoe, and E.R. McGrattan. 1996, Sticky Price Models of the Business Cycle: Can the Contract Multiplier Solve the Persistence Problem, Federal Reserve Bank of Minneapolis Staff Report 217.

Danthine, J.P. and J. Donaldson. 1990, Efficiency Wages and the Business Cycle Puzzle, European Economics Review 34, 1275-1301.

Danthine, J.P. and J. Donaldson. 1995, Non-Walrasian Economies, in: T.F. Cooley, ed., Frontiers of Business Cycle Research (Princeton University Press, Princeton) 217-242.

Gomme, P. 1994, Shirking, Unemployment and Aggregate Fluctuations, Mimeo (October).

Kiley, M.T. 1996, The Lead of Output Over Inflation in Sticky Price Models, Federal Reserve Board FEDS Working Paper 96-33.

Kimball, M.S. 1994, Labor Market Dynamics When Employment is a Worker Discipline Device, American Economic Review 84, 1045-1059. 
Mankiw, N.G. and D. Romer. 1991, New Keynesian Economics: Volumes 1 and 2 (MIT Press, Cambridge).

Phelps, E.S. 1994 Structural Slumps: The Modern Equilibrium Theory of Unemployment, Interest, and Assets (Harvard University Press, Cambridge).

Shapiro, C. and J.E. Stiglitz. 1984, Equilibrium Unemployment as a Worker Discipline Device, American Economic Review 74, 433-444.

Solow, R. 1979, Another Possible Source of Wage Stickiness, Journal of Macroeconomics 1, 79-82.

Taylor, J.B. 1980, Aggregate Dynamics and Staggered Contracts, Journal of Political Economy 88, 1-23.

Uhlig, H. and Y. Xu. 1996, Effort and the Cycle: Cyclical Implications of Efficiency Wages, Mimeo (May).

Weiss, A. 1980, Job Queues and Layoffs in Labor Markets with Flexible Wages, Journal of Political Economy 88, 526-538.

Weiss, A. 1990 Efficiency Wages: Models of Unemployment, Layoffs, and Wage Dispersion (Princeton University Press, Princeton).

Yellen, J.L. 1984, Efficiency Wage Models of Unemployment, American Economic Review (Papers and Proceedings) 74, 200-205. 